\title{
LIVES OF HOMER.
}

II.

WE have next to inquire into the relation of these lives to one another. One way of doing this is to consider the authorities they quote. The Herodotean Life naturally stands on one side; IV. also as being clearly V. less its quotations, may be neglected. I mark with an asterisk the äma $\xi$ $\phi \epsilon \rho o ́ \mu \epsilon \nu a$ in each case.

Cert.

Hellanicus fr. 6

* Cleanthes

*Eugaeon

Callicles

Democritus Troez

stemma (anon.)

Eratosthenes

*Alcidamas év $\mu o v \sigma \in l \varphi$

Pindar fr. 264

Simonides $f r .85$

Antimachus $f r .18$

Nicander $f r .14$

*Bacchylides $f r .48$

Aristotle fr. 66

Ephorus fr. 164

Aristarchus

Dion. Thrax
PLUT.

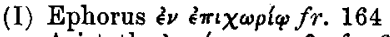

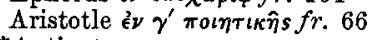
* Antipater

(II) Pindar fr. 264

Simonides $f r .85$

Antimachus $f r .18$

Nicander fr. 14

Aristotle fr, 66

Ephorus fr. 164

Aristaxchus

Dion. Thrax

Crates

VI

*Anaximenes $f r .20$

Damastes fr. 10

Pindar $f r .264$

*Theocritus

stemma (anon.)

* Hippias $f r .8$

Ephorus fr. 164

stemma (anon.)

*Timomachus

Aristotle fr. 66

Antimachus $f r .18$

*Stesimbrotus $f r .18$

*Philochorus fr. $54 \mathrm{c}$

Callicles

*A ristodemus of Nysa

*Dinarchus

Democrines

Aristotle fr. 66

* Heraclides

*Pyrander
Proc.

Hellanicus $f r .6$

Damastes fr. 10

*Pherecydes

stemma (anon.)

*Gorgias

A ristarchus

Crates

*Xenon

*Hellanicus

\section{*Hypsicrates \\ Crates \\ Eratosthenes \\ *Apollodorus}

A comparison shews at first sight that Plutarch and V. are practically identical. V. adds Bacchylides, who must have slipped out of the other 
versions. The compiler of Plutarch I. has copied fairly full versions of the same quotations of Ephorus and Aristotle, which the others reduced to a mention. Again the Certamen, Proclus, and VI. are connected. The Certamen and Proclus start off with the same historian, but immediately diverge : each has saved valuable references, which occur nowhere else. V. has added Xenon and Hellanicus, who seem to follow naturally the grammarians (Aristarchus etc.) of the other family. Both the Certamen and V. are ambraced and practically replaced by VI.: e.g. it has the Callicles and Democritus (-crines) otherwise unique of the Certamen, and the Damastes of Proclus. It also contains very nearly the whole of Plutarch and V.; that is to say it omits Simonides, Nicander, Aristarchus, Dionysius of Thrace. Yet it has portions of the vicinity of all of these writers, viz. Pindar (for Simonides); Antimachus (for Nicander); Crates (for the two other grammarians). On the evidence of quotations therefore we may confidently say that VI. is the fullest form of the common original of Cert., Plut., Proc. IV., V. Each stage has saved a little which the others lost; but the private gains of VI. are overwhelming.

Suidas does not enter into competition here: he shelters himself behind his three immediate sources. The relation of the rest seems to be-

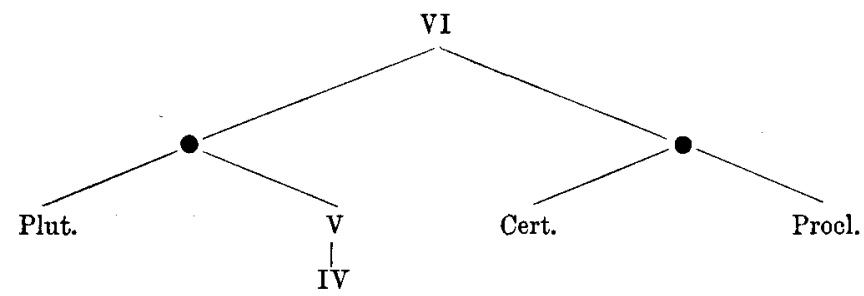

The same result may be attained by another process. The statements: made in the various Lives are now authenticated, now anonymous. If we compare them we see that nearly all fall under the same sponsors.

If we first take the vita Herodotea, where the statements are forcedly anonymous, we see that all the assertions have their authority in the other lives; only the places visited and the date are singular. The former may be assumed to hang together with the 'epigrams,' and as I have suggested these and the prose also alike come from a biographical poem. The date168 years after Troy-recurs in other authors (see I. p. 251). The short. stemma of five generations is unique, especially as introducing the interesting name 'O$\mu v^{\prime} \rho \eta s^{34}$ in the fourth generation. The mention of Crethon, however, suggests Dinarchus (vi. 28). ${ }^{35}$

In the other lives I have marked with an asterisk the statements still

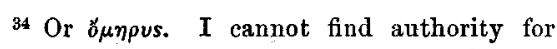

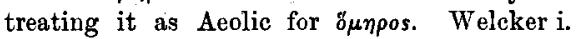
141 identified it with @apúpas!

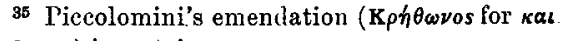
$\rho \eta \theta \omega \nu o s)$ is certain. 


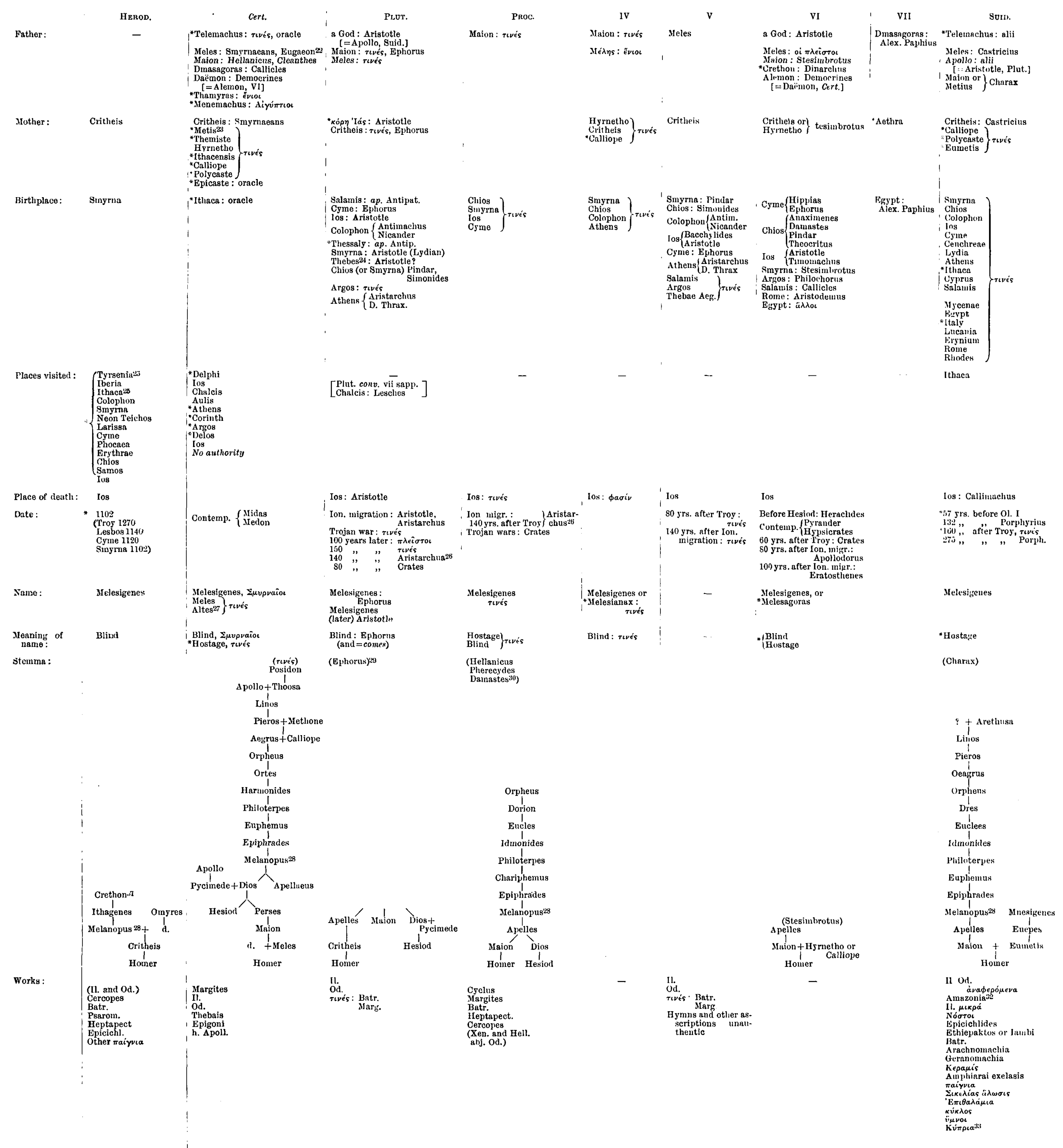

25 And Critias, F.H.G. ii. 70.

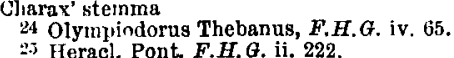

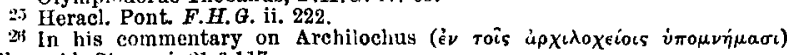

37 As A themocritus ap. schol, T. X. 51 .
39 The Cymacan hymn-writer Melauopus, Paus. v. 7.8 may have had his

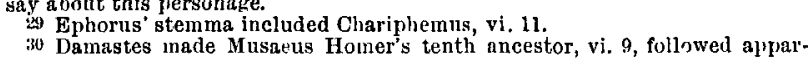
ently by Gorgias (Procl. 100. 5).

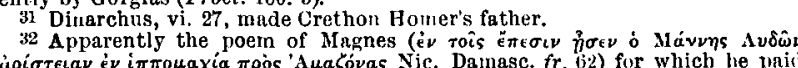

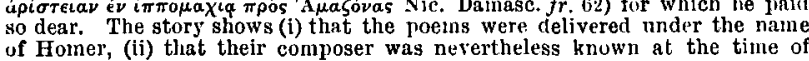

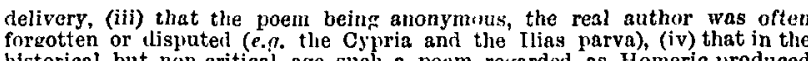
inferences upon the are and circumstances of Homer: $e . g$. from the hymn to Apollo it was inferred he was blind, and from the $A$ mazonia or a similar poen

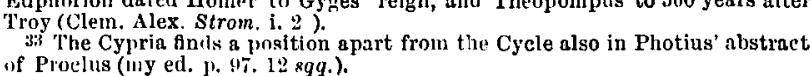
33 The Cypria fncls a position ap
"f Proclus (iny ed. 1 . 97.12 aqq.). 
left unauthenticated. It will be seen that they are not many. The Certamen brings forward several candidates for the post of mother: Calliope accurs elsewhere, Metis is presumably the Eumetis of Charax. It has also a list of places visited very different from the Herodotean : they are European. We know the source of Chalcis and Aulis, but Delphi, Athens, Corinth, and Argos are obscure. They may have come from the Hesiodic side.

The stemmata are practically the same, and go back to Stesimbrotus, Hellanicus, Pherecydes, and Damastes. There are differences between the names, which I have thought best to print as they stand, having nothing new to add. The list of works is all but identical.

Enough has been said to shew that Herod. Cert. Plut. Proc. IV. V. VI. are so many versions of one source. The best representative of this source is of course VI., but several valuable facts have escaped from it and found a home in Cert. Plut. or Proc. Suidas is in a different position. He enumerates three late sources, Charax, Porphyrius, and Castricius. One of these multiplied the birthplaces: Cenchreae and Grynium shew minute topographical knowledge, Cnossus and Lucania wide imagination. They suggest to my mind Porphyrius or Castricius, who were internationals. What was the document from which Cert. Plut. Proc. IV.-VI. all drew, and the immediate sources of Suidas also? We might put forward these same Suidean sources as the origin of Proc. IV.-VI. at least, but Castricius and Porphyrius seem unnecessarily late. An adaptation of Porphyrius would not have resulted in VI. but in a worthless screed like Iamblichus' life of Pythagoras. Or Charax? Charax furnishes a stemma, probably the mention of Callimachus, perhaps more; but a long life of Homer replete with authorities, a much fuller VI., seems out of scale in his $\mathrm{X}_{\text {povıкá. }}$

The authors quoted in Cert. Plut. Proc. IV.-VI. end with Aristarchus, Crates, and Dionysius Thrax. No later authority is quoted. This suggests an $i \pi{ }^{\prime} \mu \nu \eta \mu a$ of the first century after Christ. This was the period of the second stage in learning, the accumulation of the opinions of the previous centuries. Learned and ample commentaries on Homer have been found in. papyri of this century: Ammonius on $\Phi$ (Ox. Pap. 221), the anonymi of Ox. Pap. 1086 and 1087. In this period some one, it is idle to ask who, wrote $\pi \epsilon \rho i ~ ' 0 \mu \eta \dot{p} \rho o \nu$

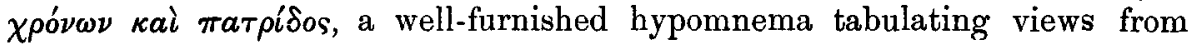
Pindar downwards. The nearest representative of this is VI. The other versions, following a natural law, diluted it till we arrive at IV. The same document lay before Philostratus Heroic. xviii. 2, Eusebius Chron. p. 36 (Scal.) and the Christians: no one wishes to charge Tatian, Athenagoras, and Clement with unnecessary research. They used a handy work of reference, and confuted the heathen out of his own mouth. They took him down too much as he stood, with his authorities in a bunch. The author was a grammarian, who had at his back the collections of the antiquarians as well as the schoolmen; the list of Homeric works, and the statement (in Proclus only) about the Chorizontes is evidently Alexandrian. 
III.

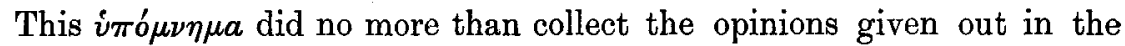
preceding centuries. To arrive at the ultimate source of the biographical tradition about Homer we must trace the fragmentary information which we possess upwards through the classical period. ${ }^{36}$

We may take for granted the technical investigations of Aristarchus, Crates, and their disciples, and the historical studies of Aristotle and the Peripatetics. The Atthidographi and other historians of the fourth and third centuries did not neglect Homer. We have seen the theses of Ephorus in

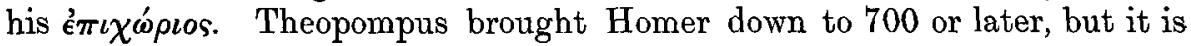
unlikely he left the subject there, and Proclus' tu quoque argument against Ephorus' etymology of öpnpos (= blind) may have been taken from Theopompus. Philochorus provided Homer with a date, and removed him from the contention of Asian towns and islands by making him an Argive. For Timaeus and Dieuchidas see the F.H.G. The Attic orators were too busy to waste time over archaeology, if they quoted Homer for their purposes and created variants for ours. To Plato we return shortly. The fifth-century logographi-all we notice orientals-held views on Homer. Hellanicus of Lesbos derived him from Orpheus, as did Pherecydes of Leros and Damastes of Sigeum. ${ }^{37} \mathrm{~A}$ tree is given by Proclus to all three: probably all three were genealogists, if Hellanicus derived Hesiod also from Orpheus ( $f r .9$ )

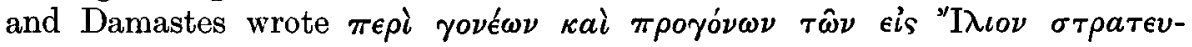
$\sigma a \mu$ é $\omega \nu$. The stemma in any case goes back to the beginning of the fifth century, and is evidently the same as that which Charax fathered centuries: later and now exists in the Vita Suidea. ${ }^{38}$ Damastes made Homer a Chian. We have also to mention Eugaeon of Samos, precise age unknown, whose work was probably $\dot{\omega} \rho \circ \iota \Sigma^{2} \alpha \iota \circ \iota$ like that of Duris later: Meles according to him was Homer's father, and the same view was held by another Samian, Asius, and by Acusilaus of Argos. None of these Samians I notice are cited for the Creophylus-story, though it must have had a certain solidity if the biographers of Pythagoras make him consort with Hermodamas the descendant. of Creophylus (Porph. vit. Pyth. 1 and 10: Iambl. id. 11: Pythagoras

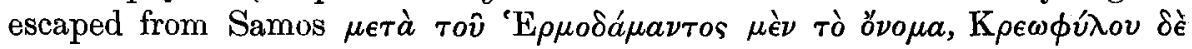

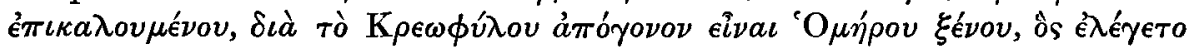

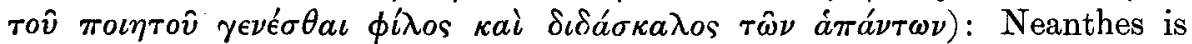
perhaps the source F.H.G. iii. 9. ${ }^{39}$ At the end of the century the sophists could not leave Homer unnoticed: Gorgias utilised, apparently, Damastes? tree, and derived him from Musaeus. Hippias, a more serious archaeologist,

36 The learned Allacei still contains the whole of extant knowledge. Welcker, $E p$. Cycl. i., Sengebusch Diss. Hom. i., Rohde Rh. Mus. 36, are more accessible. A new Notitia Homerica is not the work of an article. I wish only to exhibit the continuity.

37 Damastes made him tenth from Muscueus according to VI. 9. If this is true it does not disarrange the tree materially, as Musaeus and Orpheus were often father and son.

${ }^{38}$ See the Table and Welcker Ep. Cycl. i. 138.

39 The horographer Creophylus F.H.G. iv. 371 probably belonged to the family. 
found material in the heroic civilisation for an $\epsilon \dot{\pi} \pi \boldsymbol{i}^{\prime} \epsilon \iota \xi \iota \varsigma$, as we know from the Hippias Major. He also preceded Ephorus in making Homer a Cymaean. Critias held his father was a river ( $f r .11$ ), and as he believed Orpheus invented the hexameter ( $f r .10$ ) evidently thought he was an ancestor of Homer's. Gorgias and Hippias 'wrote about Homer,' but three writers, Stesimbrotus, Metrodorus, and Theagenes enjoy the distinction of having this specifically asserted about them. The well known passage in Tatian

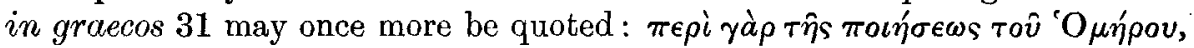

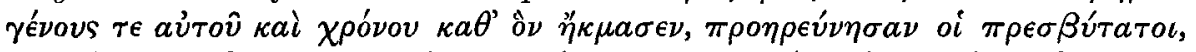

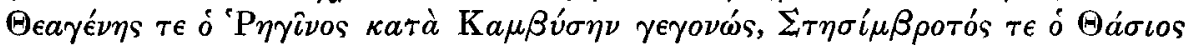

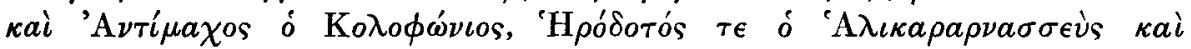

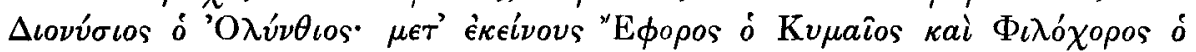

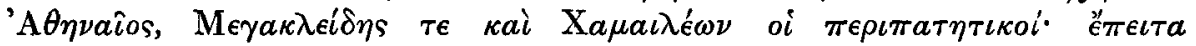

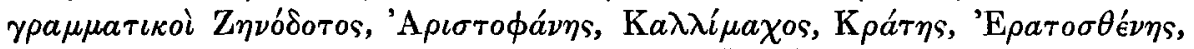

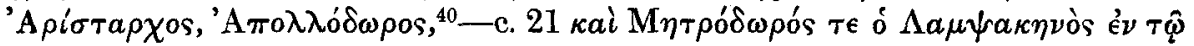

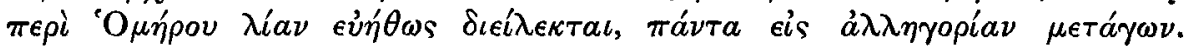
Stesimbrotus and Metrodorus are currently alluded to by Plato and Xenophon (who adds Anaximander). Of their labours we know that Stesimbrotus made Homer a Smyrnaean, and two or three of his interpretations survive; an opinion or two is cited from Metrodorus and Theagenes. Herodotus, who is still with us, is a considerable scholar. He doubts on internal not traditional evidence, the ascription of the Cypria and Epigoni, gives a very definite date, in terms of his own era, to Homer, and reveals the current opinion that there were in existence various hexameter poets believed to be older than Homer. At one moment he mistrusts this common opinion (ii. 53), at another he uses it without question (ii. 23) He hides his sources and his reasons for the ' 400 years and no more.'

Pindar, Simonides, and Bacchylides all mentioned Homer, and gave him Smyrna, Chios, and Ios for birthplaces (vit. V.); Pindar also had the family legend ( $f r .265$ ), how the Cypria was his daughter's dowry. ${ }^{41}$ These professionals lived on the turn of the century and with them and Theagenes

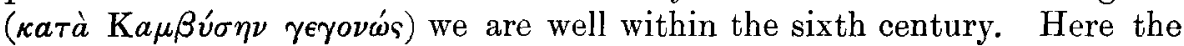
atmosphere is rare. Nearly everything has perished. If Solon and the other literature had survived there would have been frequent mentions of Homer: the further literature goes back, the more allusive it becomes. Theognis inserts a kind of précis of the Odyssey into his verse-diary (1123-8), Callinus long before credited Homer with the Thebais, Solon is our first authority for the history of tragedy. Homeric biography is touched on by Asius, a Samian, who like Pigres wrote epos and elegy, the latter humorous. ${ }^{42}$ Asius has left a quatrain (P.L.G. ii. 23), of which the second

40 This rassage, and its counterpart in Clement Al. Strom. i. 21 and Philostratus came direct from the hypomnema of s. i. A.D. (p. 21).

4l The same type of story is ombedded in the Pythagoras-cycle: Iambl. vit. Pyth. 146 the

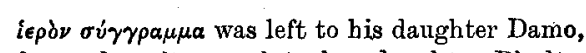
from whom it passed to her daughter Bisalte, by whose husband (and uncle) Telauges it was edited.

${ }^{42}$ Kinkel, E.G.F. 202 sqq. 


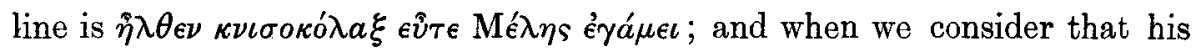
countryman Eugaeon held that Homer's father was Meles it is clear the learned ${ }^{43}$ have not been wrong in seeing here a jocose account of the established nativity of Homer. More than this the Riddle of the Lice, which the Lives give in verse form and in prose, is taken back by Hippolytus, Ref. haer. ix. 9 to Heraclitus (47 n. Bywater, 56 Diels), who thought it sufficiently $\sigma \kappa o \tau \epsilon \iota \nu o ́ \nu$ for his purpose and unpleasant enough for his humour.

We have thus followed the anecdotic and biographical tradition of Homer back to the middle of the sixth century. We next ask what the source of these anecdotes is. Have they any origin beyond natural and unsystematised tradition, and the credulity which operates on the popular conception of great men?

I wish to suggest that the source of the Homeric tradition was the guild known as the Sons of Homer. The logographi of the fifth century, Acusilaus and Hellanicus, said that the Homeridae were a Chian guild called after the poet, and I have endeavoured (C. Q. 1907. 135) to shew that the mentions of them in literature are consonant with this statement. ${ }^{44}$ Among the functions of religious guilds was that of preserving the truth or

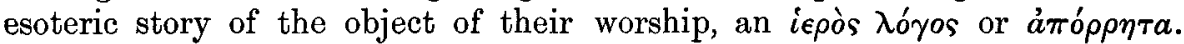
Plato and Isocrates speak of the Homeridae in terms which suggest they had a store of truth about their founder: thus Isocr. Helena $\$ 64$, Helen manifested her power to Stesichorus and compelled him to a recantation:

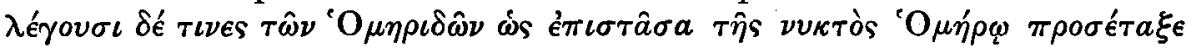

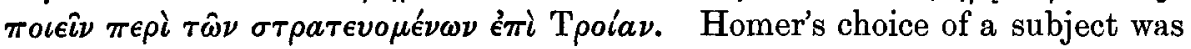
due to her bidding. Plato Rep. 599 E, implies that the Homeridae guarded the events of their founder's life and his attributes when he says that even they do not assert he founded a constitution. Certainly the Homer of the Lives is not of the lawgiver-class. The Homeridae then in the fourth century were regarded as sources for Homer's biography. It is further to be noticed that the notion of a nocturnal visit of Helen to Homer has made its way into vit. VI. in words very like those of Isocrates : v. 51 ă $\lambda \lambda \iota \iota \delta^{\prime} \phi a \sigma \iota$

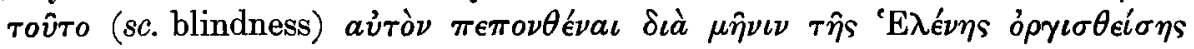

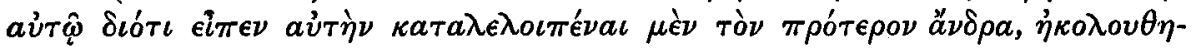

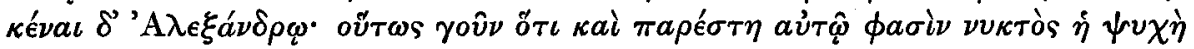

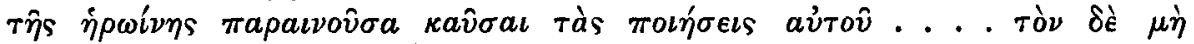

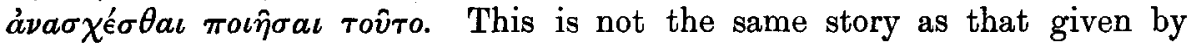
Isocrates from the Homeridae, but it represents the angry heroine penally visiting Homer, as she visited Stesichorus in the Stesichorus-story of which

\footnotetext{
43 E.g. Welcker Ep. Cycl. i. 135.

44 I adduced l.c. the Hesiodic school, who possessed all these attributes except the patronymic: I may here mention the Carpocratiani who worshipped Epiphanes son of

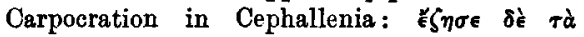
та́
}

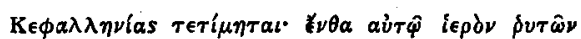

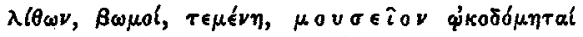

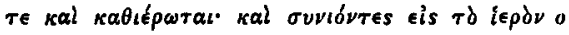

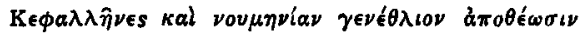

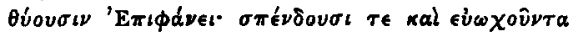

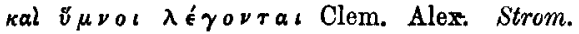
iii. 2 . 
this is a double. In this instance then there seems a palpable connexion between the Homerid doctrines and the Lives. How did they preserve their teaching, and in what form did it reach the laity? Not in biographies like the Lives, for in 600-550 prose was hardly invented. Narrative, whether historical like Magnes' 'A $\mu a$ Govía (p. 22) or personal as the poem of Aristeas, was conveyed in hexameter verse. Now the Homeridae as Plato

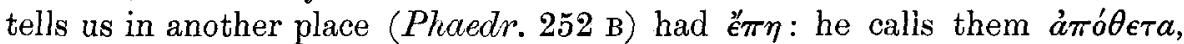
that is esoteric or 'reserved.' The two lines he quotes are hymnal, and deal

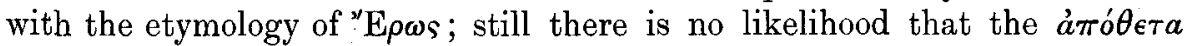
є̈ $\pi \eta$ of the Homerids were confined to theology. The accounts they gave of their Father, his commerce with heaven and his tribulations in the flesh, must have formed part of them. Now we have seen (I. p. 253) that the sections of verse put in the mouth of Homer in the Herodotean Life do not seem to be excerpts from an heroic poem or any poem except one recounting the adventures of Homer himself. They are in good epic Greek, serious and not parodic. A Life is written under the person and in the language of Herodotus, it quotes the Iliad, the Odyssey, the Cycle, and popular Volksiieder of Asia Minor; for the unidentified biographical verses which it quotes on an ample scale, no so plausible source can be found as in the ém $\eta$ of Homer's children and hierophants. There is more than this : the account of the competition between Homer and Hesiod at Chalcis at the wake of Amphidamas is given by Plutarch conv. sept. sap. c. 10 on the authority of Lesches. As I have mentioned (I. p. 253) the only Lesches known to history is the author of the Ilias parva. But to put the áróv of the two poets into a short poem describing the last days of Troy has always been difficult, and has so fiar justified the Germans' creation of a second Lesches. This difficulty vanishes if we conceive the existence of a poem or poems containing the Life of Homer. Lesches of Pyrrha in Lesbos was near the focus; and whether a member of the guild or no was a Homerid in the sense in which the scholiast on Pindar gives the title to his contemporary Cynaethus. Further, since-as we have seen I. p. 257-the verses quoted from Lesches by Plutarch are evidently the same as those utilised in the central part of the actual Certamen, it will follow that Alcidamas' source was the same Lesches. We see therefore a named Homeric poet, a contributor to the Cycle, composing a poem on some of the adventures of his Master. That this poem, the source of the Agon, was the same poem as that which inspired Cephalion in the Herodotean life is naturally uncertain. The vit. Herod. and the Agon, however, contain some of the same documents and coincide on certain points (e.g. Cert. 260, 285 vit. Herod. 135, 425). It is equally uncertain whether Lesches' poem was part of the Homerid ámótera, or if he called on their store for his work. The poem or poems were the source for the logographi and mémoiristes of the fifth century. They also supplied Asius of Samos with material for his parodies. Asius (p. 23) like Pigres ${ }^{45}$ was a serio-comic; in his lighter vein he

${ }^{45}$ Who amplified the Iliad in a serious spirit, but also wrote the Batrachomyomachia, and was credited with the Margites. 
mocked the mysteries of his own art, and gave a humorous turn to the

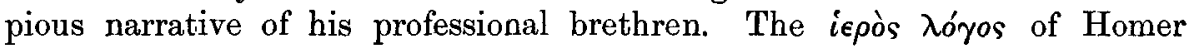
indeed lent itself to humour, and excited the contempt of Plato and Callimachus. It had been previously employed for an irreverential purpose by Sophocles (Ath. 592 A).

To resume: the age and life of Homer occupied very nearly all the Greek chronologers and annalists. They utilised in his case the same sources which they employed for their chronicles generally, namely $\dot{\Phi}$ po or local annals. The Samian $\dot{\omega} \rho \circ$, the Clazomenian, are cited, and the compilations of the Peripatetics and Alexandrians were based upon them. They supply reliable evidence for the dating of the Cycle. The personal history of Homer, more especially the marvels which attended him, were expounded by his disciples in semi-esoteric verse. The tradition of the Herodotean life and of the Certamen embody this source for us; the remaining lives, which appear to descend from a learned $\dot{i} \pi \dot{\mu} \mu \nu \eta \mu$ of the Augustan period, are more historical in character, and quote the logographi of the fifth century. They also, however, contain in different proportions a mixture of the pious traditions of the Sons of Homer. ${ }^{46}$

T. W. Allen.

40 The origin and meaning of the Homeric legend diffused by the Homeridae is a further question. A recent article by Herr E. Maass in the Neue Jahrbb. 1911, 539 ('Die Person Homers') deals with the parents' names. Maass thinks $M \in \lambda \eta \sigma \iota \gamma^{\prime} \nu \eta s$ means born on the day of the Melesia, and that $\mathbf{K} \rho t \theta \eta / s$ is mythological. $H$ is positive argument turns entirely on the forms, and these are not certain. "Soln of

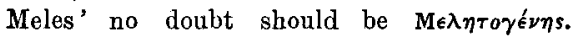
A form like this $(\mu \in \lambda \iota \tau o \gamma \in \nu \hat{\eta} \alpha)$ is actually preserved vit. Herod. 30 ; and $\mu \in \lambda \eta \sigma \iota-\mu \in \lambda \iota \sigma \sigma \iota-$ etc. may be corruptions therefrom under the influence of $\mu \epsilon \operatorname{\lambda } \iota \sigma \sigma \alpha$. As to the mother, $\kappa \iota t \theta \eta t^{\prime}$ $\kappa \rho \eta \theta \eta$ is are equally attested; the latter seems the more substantial person-name, if we

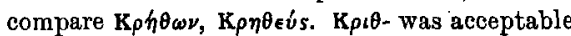
for its obvious meaning. Again it is hard to suppose that these sixth-century legends should have forgotten the Me $\lambda \hat{\eta} \sigma \iota \alpha$, if there were such a festival. If Asius parodied Meles' wedding feast, Meles (as father) must have been in existence well before his time. $\mathrm{He}$ is better attested than his festival (of which there is no mention). 